\section{En dansk økonom ser på helsetjenesten}

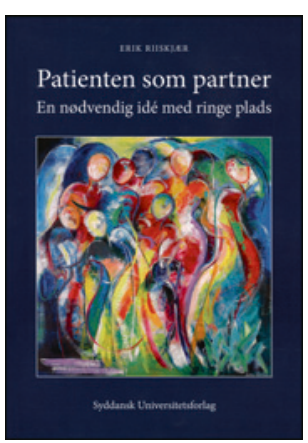

Erik Riiskjær

Patienten som partner

En nødvendig idé med ringe plads. 377 s, tab, ill. Odense: Syddansk Universitetsforlag, 2014. Pris DKK 299

ISBN 978-87-7674-821-0
Økonomer og administratorer får mye tyn av helsepersonell for tiden. Fortjent eller ikke, det kan være en god idé å kikke på hva de skriver. Erik Riiskjær er økonom med særlig interesse for organisering. Han er sjefkonsulent ved CFK - Folkesundhed og Kvalitetsudvikling i Region Midtjylland (www.cfk.rm.dk), rådgiver for Danske Patienters Videnscenter for Brugerinddragelse og underviser ved masterutdanningene ved Syddansk Universitet. Utgivelsen springer ut av et forskningsprosjekt om pasienttilfredshet $i$ et organisatorisk utviklingsperspektiv. I motsetning til mange forskere, som ser seg ferdig med et forskningsprosjekt når de vitenskapelige artiklene er publisert, har Riiskjær valgt å se forskningsfunnene $i$ et større perspektiv med denne boken.

Boken har fire deler, én om teori og metode, én om pasientroller og -opplevelser, og én om krefter bak institusjonell praksis, samt en del som peker mot en visjon om pasientene som partnere $i$ helsetjenesten. Det teoretiske utgangspunktet er institusjonell organisasjonsteori. Metoden er hermeneutisk og bygger på flere typer datagrunnlag, mye litteratur, pasienttilfredshetsundersøkelser og intervjuer. Ulike pasientroller og betydningen av såkalt pasientsentrering gjennomgås. Hvordan institusjonell praksis utvikler seg i lys av herskende logikker, offentlig styringslogikk, markedslogikk, legeprofesjonslogikk og pleieprofesjonslogikk, belyses grundig. Bokens konklusjon utkrystalliserer seg i tittelen.

Leger med interesse for helsetjenestens plass i samfunnet, og særlig de som er opptatt av sykehusenes rolle og funksjon, vil ha glede av denne boken. Også forskere på vei inn i helsetjenesteforskning vil her finne en god guide til forståelsen av de store utviklingstrekkene de siste tiårene. Jeg synes forfatteren har tatt et godt grep ved å beskrive strømmen av styringsideer, peke på hvordan de omsettes i praksis, hvilke strukturer som berøres og mekanismer som settes i spill, og endelig hvordan effekten blir for pasientene. Dette presenteres regelmessig i oversiktlige tabeller.

Forfatteren pretenderer ikke å være en objektiv observatør, men han beskriver fordeler og ulemper ved ulike styringslogikker ganske balansert. Jeg går ikke god for hvor dekkende boken er for økonomers forståelse av helsetjenesten, men konstaterer at her var mye å lære for meg. Teksten er preget av omfangsrik lesning (28 sider litteraturreferanser) og klar skriftlig fremstillingsevne. Det er dansk helsestell som er emnet, men praktisk talt alt er relevant for norske forhold. Jeg vil anbefale boken spesielt sterkt til helsepolitikere og Legeforeningens tillitsvalgte.

\section{Grundig om aldringsprosessen for spesielt interesserte}

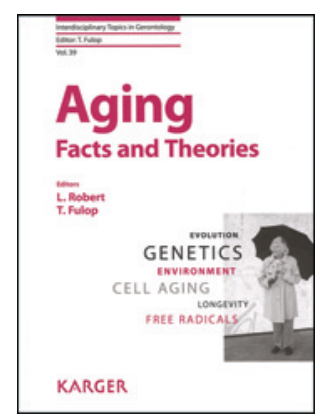

Ladislas Robert, Tamas Fulop, red.

\section{Aging}

Facts and theories. 215 s, tab, ill. Basel:

Karger, 2014. Pris CHF 196

ISBN 978-3-318-02652-8

På bokens bakside angis målgruppen å være ganske bred, fra spesialister på feltet til forskere og andre vitenskapsfolk innenfor medisinske og sosiale fag.

Forfatterne skriver kunnskapsrikt, omfattende og detaljert om teorier og fakta omkring emnet gerontologi. Emnene strekker seg fra evolusjonsbaserte teorier og «biogerontologi» til fordypning i oksidativt stress og ødeleggelse av mitokondrienes DNA.

De 12 kapitlene tar for seg aldringsprosessen og diskuterer teorier rundt det cellulære og molekylære nivået av denne, men de fremstår ikke samlet som en lærebok. Kapitlene har ulike innfallsvinkler og er ganske forskjellige i form og kvalitet. Noen av dem er delvis overlappende. Hvert kapittel har mange referanser som stort sett er hentet fra publikasjoner jevnt fordelt over de siste 50 år. Boken trekker inn diskusjoner som har pågått like lenge omkring hvordan man bør tolke funn som har gitt opphav til ulike teorier om hvorfor og hvordan vi eldes. Ved flere anledninger bidrar forfatterne også med egne synspunkter i denne debatten.

Boken er på et dels ikke så lett forståelig engelsk, er uten farger og har få illustrasjoner. Setningene er ofte lange og har mange fremmedord. Likevel vil mange av kapitlene antakelig ikke være så tunge å lese for en som er litt inne i emnet. For meg som ikke er noen kløpper i engelsk, og som hele tiden vil lete etter noe som er direkte klinisk relevant, blir hele boken i tyngste laget. Jeg savner et oversiktskapittel med noe mer basisinformasjon og forklaringer til ord og uttrykk som brukes. Og ikke minst kunne flere illustrasjoner gjort boken mer leservennlig.

Jeg vil tro at denne utgivelsen er mest interessant for dem som har fordypet seg en del $i$ aldringsprosessen fra før, og helst hatt interesse for gerontologien så lenge at man selv har begynt å føle den på kroppen. For en som forsker på området, kan boken nok være nyttig.

For geriatere og leger i spesialisering i geriatri som ønsker å få bedre innsikt $i$ aldringsprosessens betydning for de mange tilstander geriatrien omfatter, finnes det mer relevante og lettleste bøker på markedet.

\section{Hanne Frøyshov}

Overlege, Medisinsk avdeling

Universitetssykehuset Nord-Norge

Harstad 